\title{
UJI SIFAT FISIKO KIMIA DAN ORGANOLEPTIK MINUMAN YOGHURT NGEBOON PANORAMA INDONESIA
}

\section{Physicochemical Properties and Organoleptic Test of Yoghurt Ngeboon Panorama Indonesia}

Muhammad Zainul Arifin, Shinta Maharani, Sarah Istiqomah Widiaputri

Program Studi Pendidikan Teknologi Agroindustri, Fakultas Pendidikan Teknologi dan Kejuruan

Universitas Pendidikan Indonesia, Bandung, Indonesia

E-mail: muhammadzainularifin13@student.upi.edu

\begin{abstract}
ABSTRAK
Yoghurt adalah minuman yang saat ini sangat terkenal karena memiliki banyak manfaat bagi tubuh manusia. Yoghurt Ngeboon Panorama Indonesia terbuat dari susu yang telah di fermentasi dengan penambahan puree buah, gula, dan jelly sehingga memiliki karakteristik rasa yang unik dan diminati oleh semua kalangan baik ibu-ibu, pekerja kantoran hingga anak-anak. Puree buah yang ditambahkan membuat yoghurt ini lebih kaya akan gizi dan manfaatnya bagi tubuh karena memiliki gula alami, serat, berbagai vitamin, mineral, antioksidan dan polifenol. Tujuan penelitian ini dilakukan untuk mengetahui karakteristik fisik, kimia, dan organoleptik dari varian rasa yoghurt yang telah diproduksi oleh Ngeboon Panorama Indonesia. Rancangan percobaan yang digunakan adalah Rancangan Acak Lengkap (RAL) dengan satu faktor yaitu varian rasa yoghurt (stroberi, nanas, jambu dan tomat). Data yang didapat dianalisis dengan ANOVA (Analysis of Variance) pada $\alpha=5 \%$. Bila terdapat perbedaan maka dilakukan dengan uji DMRT (Duncan's Multiple Range Test). Varian rasa yoghurt memberikan pengaruh yang nyata terhadap nilai lightness, redness, yellowness karena setiap buah memiliki kepekatan warna dan senyawa pigmen yang berbeda. Yoghurt dengan rasa stroberi memiliki kadar polifenol $(632,847 \mathrm{mg} / \mathrm{kg})$ dan aktivitas antioksidan $(83,828 \%)$ tertinggi dibandingkan dengan yoghurt rasa lainnya. Dari tingkat kesukaan kenampakan, warna, aroma, tekstur, dan rasa pada semua varian rasa yoghurt ini sangat disukai oleh semua panelis kecuali yoghurt varian rasa tomat pada tingkat kesukaan warna hanya mendapatkan nilai suka dari semua panelis.
\end{abstract}

Kata kunci: antioksidan, polifenol, puree buah, yoghurt

\begin{abstract}
Yoghurt is a drink that is currently very famous because it has many benefits for the human body. Ngeboon Panorama Indonesia Yoghurt is made from fermented milk with the addition of fruit puree, sugar, and jelly so that it has unique taste characteristics and is in demand by all groups of mothers, office workers to children. The fruit puree added makes this yoghurt richer in nutrition and benefits for the body because it has natural sugars, fiber, various vitamins, minerals, antioxidants and polyphenols. The purpose of this study was to determine the physical, chemical, and organoleptic characteristics of the yoghurt flavor variants that have been produced by Ngeboon Panorama Indonesia. The experimental design used was a Completely Randomized Design (CRD) with one factor, namely yoghurt flavor variants (strawberries, pineapple, guava and tomatoes). The data obtained were analyzed with ANOVA (Analysis of Variance) at $\alpha=5 \%$. If there is a difference, it is done by DMRT (Duncan's Multiple Range Test) test. Yoghurt flavor variants have a significant effect on the value of lightness, redness, yellowness because each fruit has a different color density and pigment compound. Yoghurt with strawberry flavor has the highest levels of polyphenols $(632,847 \mathrm{mg} / \mathrm{kg})$ and antioxidant activity (83.828\%) compared to other flavored yoghurt. From the level of likeness of appearance, color, aroma, texture, and taste in all variants of the flavor of yoghurt is very liked by all panelists except the tomato flavor variant yoghurt at the color preference level only gets a liking value from all panelists.
\end{abstract}

Keywords: antioxidants, polyphenols, fruit puree, yoghurt 


\section{PENDAHULUAN}

Yoghurt merupakan salah satu produk fermentasi yang banyak disukai oleh masyarakat Indonesia. Yoghurt diperoleh dari fermentasi susu dan/atau susu rekonstitusi dengan menggunakan bakteri Lactobacillus bulgaricus dan Streptococcus thermophillus dan/atau bakteri asam laktat lain yang sesuai, dengan/atau tanpa penambahan bahan pangan lain dan bahan tambahan pangan yang diizinkan (SNI 2981, 2009). Bakteri tersebut mengubah gula susu (laktosa) yang terdapat dalam susu menjadi asam laktat hal ini menyebabkan yoghurt berasa asam sehingga baik dan aman bagi penderita intoleransi laktosa atau orang yang tidak bisa meminum susu.

Yoghurt mempunyai nilai gizi yang lebih tinggi dibandingkan dengan susu segar sebagai bahan bakunya. Menurut Effendi (2012) manfaat dari yoghurt ialah : 1) Yoghurt dapat menghasilkan zat-zat gizi yang diperlukan oleh hati sehingga bermanfaat untuk mecegah penyakit kanker, 2) Yoghurt diyakini dapat memperpanjang umur, 3) Yoghurt memiliki mikroba yang bermanfaat untuk membantu proses pencernaan dalam tubuh, 4) Kandungan lemaknya lebih rendah dari susu sehingga cocok bagi mereka yang sedang menjalankan diet rendah kalori, 5) Yoghurt dapat membantu proses penyembuhan pada lambung dan usus yang luka, 6) Mengkonsumsinya secara teratur dapat membantu menurunkan kadar kolesterol dalam darah. Seiring berkembangnya zaman yoghurt bukan lagi produk yang susah untuk dicari keberadaannya dan makin banyak varian jenis yang disediakan seperti yoghurt plain, yoghurt dengan berbagai rasa buah, dan yoghurt dengan penambahan buah asli.

Minuman yoghurt Ngeboon Panorama Indonesia adalah susu yang telah difermentasi dengan bakteri baik yaitu Lactobacillus bulgaricus, Lactobacillus acidophilus, dan Streptococcus thermophilus dengan penambahan buah asli yang dijadikan puree dan jelly yang kaya akan serat juga tidak menambahkan pengawet dan bahan tambahan pangan kimiawi lainnya dalam pembuatannya. Bahan baku yang digunakan berasal dari petani lokal dengan kualitas mutu yang terjamin. Ngeboon Panorama Indonesia sudah memiliki 4 varian rasa dalam produk yoghurtnya yaitu stroberi, nanas, tomat dan jambu. Produk tersebut belum pernah di analasis kandungan fisiko kimianya serta preferensi konsumennya.

Dalam penelitian Samichah dan Syauqy (2014) mengatakan bahwa yoghurt plain memiliki aktivitas antioksidan $28,49 \%$, dan setelah ditambahkan selai stroberi, black carrot dan labu kuning sebanyak $1,5 \%$ secara berurutan aktivitas antioksidannya meningkat menjadi $40,12 \%, 31,69 \%$, dan $36,34 \%$. Senyawa antioksidan yang paling berlimpah pada buah-buahan adalah karotenoid, flavonoid, fenolik, vitamin C, vitamin E, vitamin A, dan betalain (Nurliyana dkk, 2010). Buah-buahan memiliki banyak manfaat bagi tubuh kita karena memiliki kandungan gizi yang berlimpah juga antara lain gula alami, serat, berbagai vitamin, mineral, antioksidan dan polifenol. Berdasarkan potensi dari penambahan puree buah kedalam yoghurt yang menjadikannya produk kaya akan gizi dan manfaat, penulis akan melakukan penelitian dengan yoghurt yang diproduksi oleh Ngeboon Panorama Indonesia dengan mengangkat topik berjudul "Uji Sifat Fisiko Kimia dan Organoleptik Minuman Yoghurt Ngeeboon Panorama Indonesia".

\section{METODE}

\section{Waktu dan Tempat Penelitian}

Penelitian dilakukan pada bulan Oktober - November 2019 di Laboratorium Teknologi Pengolahan Pangan, Laboratorium Instrumen dan Laboratorium Pengawasan Mutu Program Studi Pendidikan Teknologi Agroindustri, Fakultas Pendidikan Teknologi dan Kejuruan Universitas Pendidikan Indonesia.

\footnotetext{
Alat

Alat-alat yang digunakan dalam pengujian organoleptik adalah gelas sloki dan sendok teh. Alat yang digunakan dalam analisis kimiawi yoghurt adalah sentrifugasi, spektrofotometer UV-VIS, kuvet, mikropipet, pipet volume, vortex mixer, neraca analitik, rak tabung rekasi, tabung reaksi, corong, botol berwarna coklat, labu ukur, gelas piala, dan erlenmeyer.
} 


\section{Bahan}

Bahan yang digunakan dalam penelitian ini adalah yoghurt dengan berbagai varian rasa yaitu stroberi, nanas, jambu, dan tomat yang diperoleh dari Ngeboon Panorama Indonesia selaku sebuah startup yang mengembangkan komoditas lokal dengan menjadikannya produk diversifikasi pangan yang sehat. Bahan yang digunakan dalam analisis kimiawi adalah etanol $95 \%$, aquades, larutan DPPH, asam galat, Fenol - Folin Ciocalteu 10\%, Natrium Karbonat $\left(\mathrm{Na}_{2} \mathrm{CO}_{3}\right) 7,5 \%$.

\section{Prosedur Penelitian}

Pada penelitian ini pengujian dilakukan terhadap yoghurt Ngeboon Panorama Indonesia. Penelitian dilaksanakan mengggunakan metode eksperimen dan rancangan percobaan Rancangan Acak Lengkap (RAL) dengan satu faktor yaitu varian rasa yoghurt. Parameter penelitiannya adalah nilai warna, kadar polifenol, ativitas antioksidan, dan organoleptik yoghurt semua varian rasa. Perlakuan dilakukan dengan dua kali ulangan perlakuan dan tiga kali ulangan analisis. Berikut ini prosedur penelitian yang dilakukan yaitu :

\section{Pengukuran Nilai Warna (LAB Color Model)}

Sampel yoghurt yang sudah disiapkan dalam kemasan plastik berbahan pet, kemudian color reader ditempelkan pada permukaan kemasan. Tombol pembacaan diatur pada $\mathrm{L}^{*}$ (lightness), $\mathrm{a}^{*}$ (redness) dan $\mathrm{b}^{*}$ (yellowness) dan tombol target ditekan, kemudian hasil dari pembacaan alat tersebut dicatat.

\section{Ekstraksi Sampel Yoghurt}

Ekstraksi sampel yoghurt geboon Panorama Indonesia mengikuti metode yang dijelaskan oleh Zainoldin dan Baba (2009) dengan modifikasi. Sampel yoghurt 5 gram dicampurkan dengan $1.25 \mathrm{ml}$ aquades dan $\mathrm{pH}$ harus disesuaikan terlebih dahulu menjadi 4 dengan penambahan $1 \mathrm{M}$ $\mathrm{HCl}$ kemudian sentrifuse (4000rpm, selama 20 menit). Supernatan dipisahkan dan disesuaikan kembali $\mathrm{pH}$ nya menjadi 7 dengan menggunakan $\mathrm{NaOH}$. Supernatan yang sudah dibasakan, disentrifuse kembali (4000rpm, selama 20 menit) dan diambil supernatan kedua untuk digunakan sebagai analisis.

\section{Pengukuran Kadar Polifenol}

Total kadar polifenol diukur dengan menggunakan yoghurt ekstrak $1 \mathrm{ml}$ dimasukan ke dalam tabung ulir dan ditambahkan $1 \mathrm{ml}$ etanol $95 \%$ dan aquades $5 \mathrm{ml}$. Sampel ditambahkan 0,5 $\mathrm{ml}$ folin-ciiocalteu $50 \%$ (v/v). Setelah 5 menit, ditambahkan $1 \mathrm{ml} \mathrm{Na}_{2} \mathrm{CO}_{3} 5 \%$ dan campuran didiamkan selama 60 menit dalam ruang tertutup. Selanjutnya adsorbansi dihitung dengan gelombang $725 \mathrm{~nm}$ dan nilainya dikonversi sebagai total polifenol (GAE/g). Kurva standar yang digunakan pada pengukuran kadar polifenol ini yaitu kurva standar asam galat. (Zainoldin dan Baba, 2009)

\section{Pengukuran Aktivitas Antioksidan}

Aktivitas antioksidan yoghurt diukur dengan menggunakan metode berdasarkan Zainoldin dan Baba (2009). Ekstrak sampel (0,25 ml) dicampurkan dengan $3 \mathrm{ml}$ DPPH $60 \mu \mathrm{M}$. Adsorbansi diukur dengan gelombang $517 \mathrm{~nm}$. Adsorbansi dibandingkan dengan Control yang berisi aquades $(0,25 \mathrm{ml})$. Aktivitas antioksidan dihitung berdasarkan perhitungan persen inhibisi. Persen inhibisi adalah perbandingan antara selisih dari absorbansi blanko dan absorbansi sampel dengan absorbansi blanko.

\section{Pengujian Organoleptik}

Pada pengujian organoleptik dilakukan dengan uji hedonik. Uji hedonik merupakan pengujian untuk mengetahui tingkat kesukaan maupun ketidaksukaan panelis terhadap produk yang diujikan Pada pengujian hedonik kali ini, dicantumkan skala hedonik dengan skala 1-5 yaitu ( $1=$ sangat tidak suka), ( $2=$ tidak suka), ( $3=$ suka), ( $4=$ sangat suka) dan $(5=$ sangat suka sekali) (Setyaningsih dkk, 2010). 
Pengujian ini dilakukan dengan cara meminta 15 panelis agak terlatih untuk mengamati karakteristik organoleptik (kenampakan, warna, aroma, tekstur, dan rasa) yoghurt Ngeboon Panorama Indonesia.

\section{Analisis Data}

Data yang diperoleh dari hasil pengamatan dianalisis secara statistik untuk mengetahui apakah ada perbedaan antara perlakuan dengan menggunakan uji ANOVA (Analysis of Variance) pada $\alpha=5 \%$. Bila terdapat perbedaan maka dilakukan dengan uji DMRT (Duncan's Multiple Range Test).

\section{HASIL DAN PEMBAHASAN \\ Nilai Warna LAB Yoghurt Ngeboon Panorama Indonesia}

Kualitas mutu suatu produk dapat dinilai dari warnanya. $L A B$ Color Model berdasar pada presepsi manusia atas warna merupakan salah satu dari beberapa model warna yang diproduksi oleh Commision Internationale d'Eclairage (CIE), yaitu suatu organisasi yang membuat standar untuk semua aspek cahaya (Indrayani, 2012). Nilai numerik di dalam LAB menguraikan semua warna dilihat dengan penglihatan normal. LAB dianggap sebagai suatu device-independent color model. Model ini menggunakan tiga komponen warna yaitu $L^{*}$ sebagai lightness (pencahayaan), $a^{*}$ dan $b^{*}$ sebagai dimensi warna yang berlawanan.

Tabel 1. Nilai Warna LAB Varian Rasa Yoghurt Ngeboon Panorama Indonesia

\begin{tabular}{cccc}
\hline Varian Rasa Yoghurt & ${\text { Nilai } \mathbf{L}^{*}}^{*}$ & ${\text { Nilai } \mathbf{a}^{*}}^{*}$ & ${\text { Nilai } \mathbf{b}^{*}}^{\mathbf{c}}$ \\
\hline Stroberi & $72,783 \pm 1,089^{\mathrm{a}}$ & $3,333 \pm 1,134^{\mathrm{c}}$ & $6,050 \pm 0,446^{\mathrm{a}}$ \\
\hline Nanas & $80,000 \pm 0,881^{\mathrm{b}}$ & $-2,217 \pm 0,172^{\mathrm{a}}$ & $9,800 \pm 0,529^{\mathrm{bc}}$ \\
\hline Jambu & $77,617 \pm 1,232^{\mathrm{b}}$ & $0,717 \pm 0,271^{\mathrm{b}}$ & $7,933 \pm 0,585^{\mathrm{ab}}$ \\
\hline Tomat & $78,667 \pm 1,500^{\mathrm{b}}$ & $0,750 \pm 0,572^{\mathrm{b}}$ & $10,233 \pm 0,761^{\mathrm{c}}$ \\
\hline
\end{tabular}

Keterangan: Notasi yang sama menunjukan tidak berbeda nyata pada taraf signifikan $\alpha=5 \%$ menurut uji DMRT

Lightness $\left(L^{*}\right)$ menunjukkan interval kecerahan pada kenampakan suatu bahan dari gelap (0) hingga cerah (100). Nilai L* Yoghurt Ngeboon Panorama Indonesia berkisar 72,783 hingga 80,000 . Yoghurt rasa nanas menunjukan warna yang paling cerah dibandingkan dengan yoghurt rasa lainnya dengan nilai $L^{*} 80.000$. Menurut Siregar, M. R. dkk (2016) nanas memiliki pigmen karatenoid (oranye) dan xantofil (kuning). Hal ini menyebabkan buah nanas memiliki warna kuning lebih muda dibandingkan dengan buah lainnya.

Redness $\left(\mathrm{a}^{*}\right)$ menunjukkan warna kromatik campuran merah-hijau dengan nilai $+\mathrm{a}^{*}$ dari 0 sampai +80 untuk warna merah dan nilai $-a^{*}$ dari 0 sampai -80 untuk warna hijau. Yoghurt rasa nanas menghasilkan nilai $a^{*}-2,217$ (hijau) berbeda dengan yoghurt rasa lainnya yang memiliki warna merah. Buah stroberi kaya akan pigmen warna antosianin yang mengandung antioksidan tinggi (Sumarlan, S. H., 2018). Antosianin dapat berperan sebagai antioksidan dan dapat juga sebagai sumber pewarna alami yang memberikan pigmen bewarna merah (Inggrid dan Iskandar, 2016). Nilai $+a^{*}$ (redness) pada yoghurt rasa tomat berasal dari senyawa yang ada dalam tomat. Senyawa tersebut antara lain yaitu likopen sebanyak $6,84 \mathrm{mg} / 100 \mathrm{~g}, \beta$-karoten sebanyak 2,96 $\mathrm{mg} / 100 \mathrm{~g}$, dan $\mathrm{y}$-karoten sebanyak $1,44 \mathrm{mg} / 100 \mathrm{~g}$ (Cenariu dkk, 2015). Nilai $\mathrm{a}^{*}$ yoghurt rasa tomat lebih rendah dibandingkan dengan nilai $a^{*}$ yoghurt rasa stroberi, padahal tomat mentah memiliki warna yang sangat merah. Hal ini dijelaskan oleh penelitian yang dilakukan Abdul-Hammed dkk (2015) yang menyatakan bahwa kandungan likopen tomat menurun dengan meningkatnya perlakuan panas dan waktu pemrosesan. Hasil yang diperoleh menunjukkan bahwa kandungan likopen pada tomat yang diolah dengan suhu $60^{\circ} \mathrm{C}$ selama 90 menit menurun sebanyak $42 \%$, sementara itu pemrosesan pada $120^{\circ} \mathrm{C}$ selama 90 menit menunjukan penurunan likopen sebanyak $56 \%$. Nilai $a^{*}$ yoghurt rasa jambu tidak berbeda nyata dengan yoghurt rasa tomat karena jambu memiliki kandungan likopen dan beta karoten seperti tomat. 
Yellowness $\left(b^{*}\right)$ menunjukkan warna kromatik campuran biru-kuning dengan nilai $+b^{*}$ dari 0 sampai +70 untuk warna kuning dan nilai $-b^{*}$ dari 0 sampai -70 untuk warna biru. Nilai $b^{*}$ yoghurt Ngeboon Panorama Indonesia berkisar 6,050 hingga 10,233. Nilai $b^{*}$ tertinggi terdapat pada yoghurt rasa tomat. Hal ini kemungkinan karena tomat yang digunakan pada pembuatan produk merupakan tomat yang masih muda sehingga yoghurt memiliki warna kuning yang lebih tinggi. Diketahui bahwa buah tomat mengandung pigmen karotenoid (oranye), terutama likopen (merah) dan $\beta$-karoten yang merupakan komponen utama penentu warna pada buah tomat masak (Novita dkk, 2015).

\section{Kadar Polifenol Yoghurt Ngeboon Panorama Indonesia}

Polifenol merupakan senyawa fitokimia yang secara alami terkandung dalam tanaman yang memberikannya berbagai warna (pigmen). Senyawa polifenol yang biasa terkandung dalam buah dan sayur adalah asam fenolik, flavonoid, stilben (resveratrol), dan lignan. Polifenol yang masuk ke dalam tubuh kita juga mampu melindungi sel-sel tubuh dari kerusakan akibat radikal bebas.

Mengukur kadar pelofenol ditentukan dengan menggunakan metode Folin Ciocalteau. Prinsip pengujian polifenol dengan metode Follin Ciocalteu adalah reduksi gugus hidroksil fenolik yang terjadi pada kondisi alkali dimana mereduksi kompleks fosfotungstat-fosfomolibdat dengan reagen, sehingga berubah menjadi warna biru. Pada penentuan kadar fenol ini digunakan standar asam galat. Hal ini dikarenakan asam galat lebih stabil dibandingkan dengan asam tanat yang juga bisa digunakan untuk membuat standar (Rahayu, 2019). Hasil uji kadar polifenol Yoghurt Ngeboon Panorama Indonesia dapat dilihat pada Gambar 1.

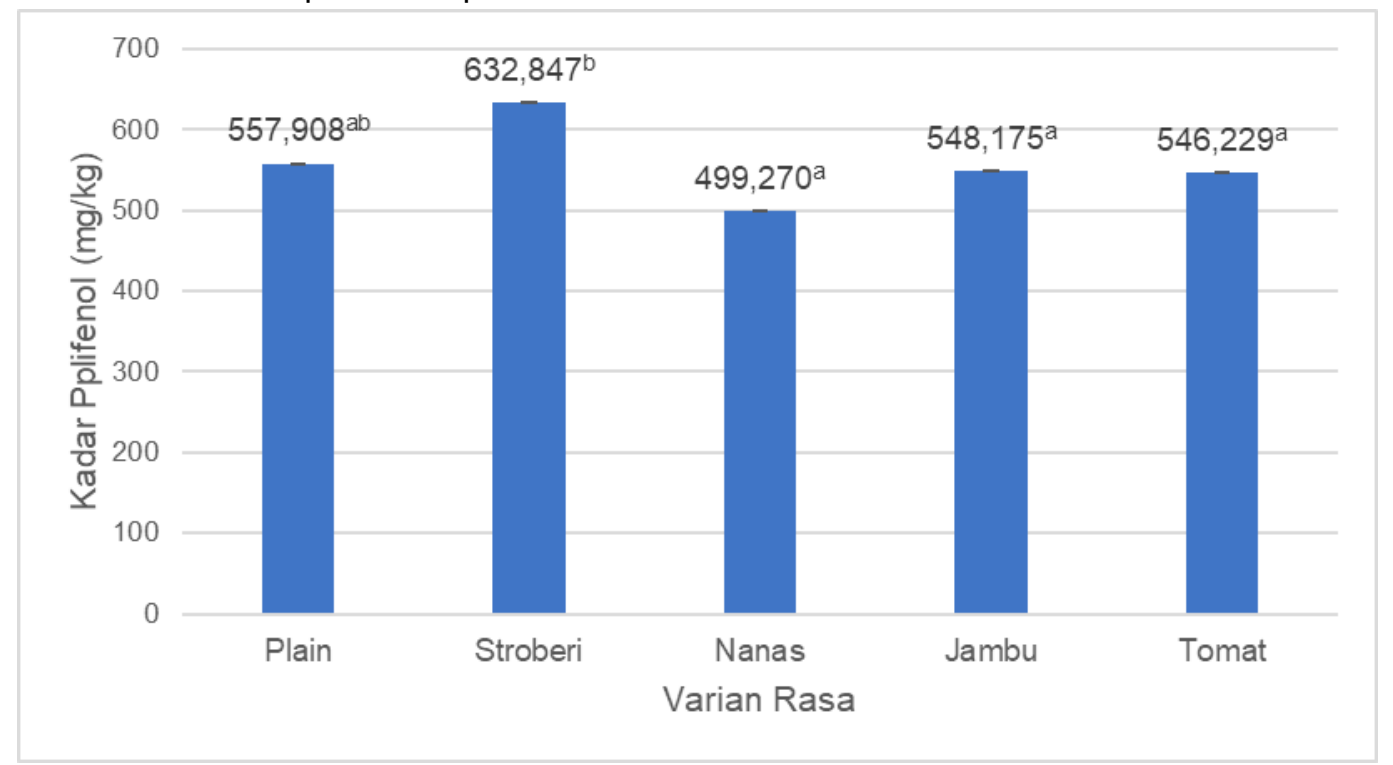

Gambar 1. Grafik Kadar Total Polifenol Yoghurt Ngeboon Panorama Indonesia

Berdasarkan hasil pengujian pada Gambar 1 menunjukan bahwa kadar polifenol tertinggi terdapat pada yoghurt rasa stroberi dan kadar polifenol terendah terdapat pada yoghurt rasa nanas. Akan tetapi, kadar polifenol yoghurt plain lebih tinggi dibandingkan dengan yoghurt rasa nanas, jambu, dan tomat. Hal ini tidak sesuai dengan teori bahwa penambahan buah dapat meningkatkan kadar polifenol yoghurt seperti yang dikatakan oleh Supriyono dkk (2014) bahwa bakteri Lactobacillus Bulgaricus membentuk asam-asam organik salah satunya adalah polifenol yang merupakan hasil metabolisme sekunder. Asam yang terbentuk dihasilkan oleh Lactobacillus Bulgaricus yaitu dengan mengkonversi glukosa menjadi asam laktat. Perubahan kadar total polifenol ini berhubungan dengan jumlah substrat yang makin tersedia dengan jumlah glukosa yang meningkat. 
Ketidaksesuaian ini diduga terjadi karena adanya perbedaan waktu pada saat pengujian yoghurt plain dimana umur simpan yoghurt plain lebih lama satu hari dibandingkan dengan yoghurt lainnya. Hal ini didukung oleh penelitian Chandra (2013) yang menyatakan bahwa adanya peningkatan polifenol dan antioksidan selama penyimpanan yoghurt anggur bali selama 21 hari.

Polifenol tertinggi terdapat pada yoghurt rasa stroberi. Senyawa fitokimia yang terdapat dalam stroberi adalah golongan fenol, komponen yang terbanyak adalah flavonoid (antosianin dan flavonol) dan tanin sebagai komponen minor. Antosinain merupakan senyawa penting dalam stroberi termasuk golongan senyawa polifenol, kandungan antosianin sekitar 150-600 mg/kg buah segar (Wijaya, 2018). Yoghurt dengan kandungan polifenol terendah terdapat pada rasa nanas. Pada buah nanas terdapat terdapat senyawa polifenol yaitu flavonoid. Flavonoid terdiri dari myricetin, kaempferol, luteolin, apigenin, dan quercetin. (Sanggih dkk, 2019). Polifenol pada buah jambu biji adalah free elagic acid dan glikosida dari myricetin dan apiganin (Sarkar, 2018). Polifenol dalam buah tomat adalah quarcetin, kaemprefol, naringenin (Ikhsanudin dan Ningsih, 2017).

\section{Aktivitas Antioksidan Yoghurt Ngeboon Panorama Indonesia}

Antioksidan merupakan molekul yang mampu memperlambat atau mencegah proses oksidasi molekul lain. Oksidasi adalah reaksi kimia yang dapat menghasilkan radikal bebas, sehingga memicu reaksi berantai yang dapat merusak sel. Yoghurt adalah salah satu produk yang memiliki khasiat antioksidan. Proses pengolahan dengan fermentasi dapat meningkatkan aktivitas antioksidan sehingga akan meningkatkan nilai fungsional suatu bahan pangan (Putriningtyas dan Wahyuningsih, 2017). Hasil uji aktivitas antioksidan Yoghurt Ngeboon Panorama Indonesia dapat dilihat pada Gambar 2.

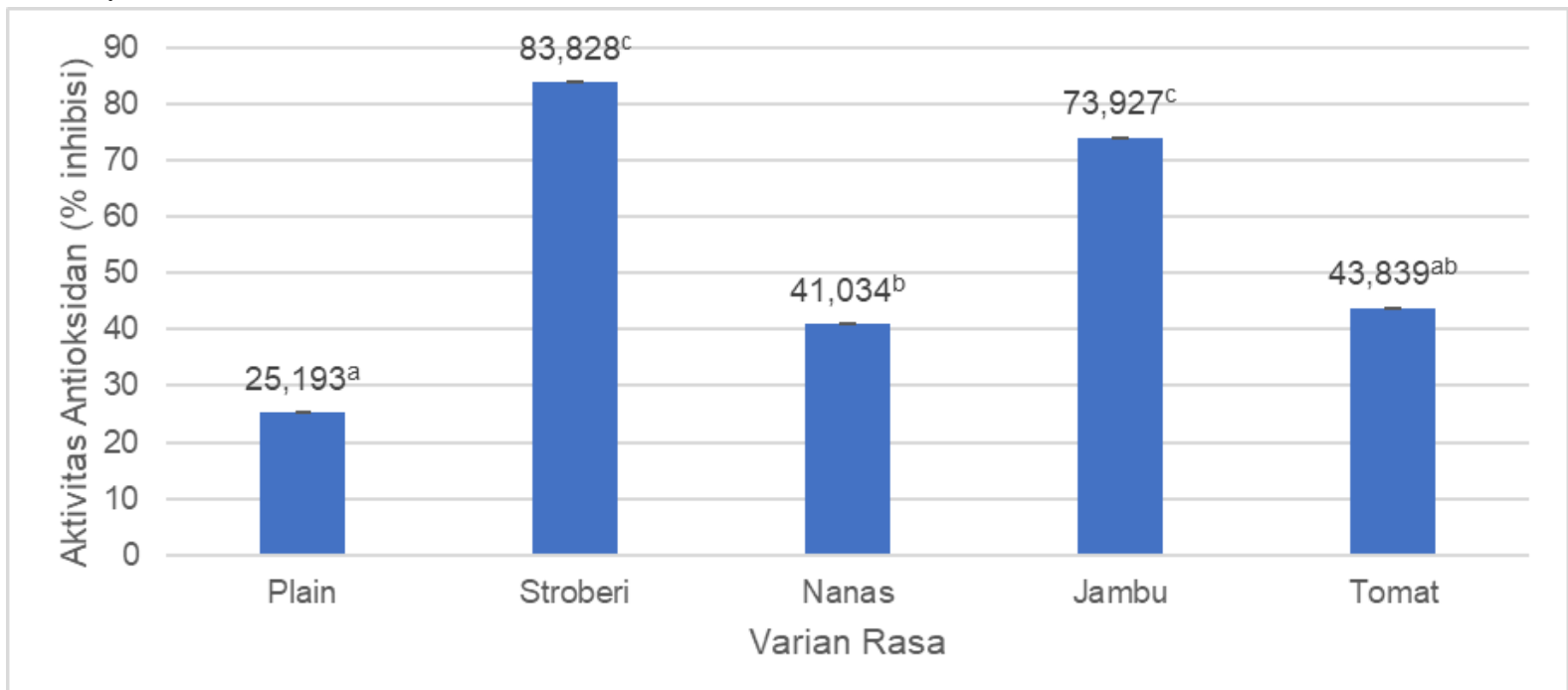

Gambar 2. Grafik Persentase Inhibisi Aktivitas Antioksidan Yoghurt Ngeboon Panorama Indonesia

Berdasarkan hasil yang sudah di dapatkan menunjukan bahwa semua yoghurt dengan penambahan puree buah memiliki aktivitas antioksidan yang lebih tinggi dibandingkan dengan yoghurt plain. Hal ini relevan dengan penelitian Samichah dan Syauqy (2014) yang mengatakan bahwa yoghurt plain memiliki aktivitas antioksidan $28,49 \%$, dan setelah ditambahkan selai stroberi, black carrot dan labu kuning sebanyak $1,5 \%$ secara berurutan aktivitas antioksidannya meningkat menjadi $40,12 \%, 31,69 \%$, dan $36,34 \%$. Dapat disimpulkan bahwa dengan penambahan puree buah, yoghurt mendapatakan aktivitas antioksidan yang lebih besar dibandingkan pada yoghurt plain pada umumnya.

Berdasarkan hasil pengujian pada Gambar 2 menunjukan bahwa aktivitas antioksidan tertinggi sampai yang terendah berturut-turut adalah yoghurt rasa stroberi, jambu, tomat dan nanas. Hal ini sesuai dengan Gambar 1 dan Gambar 2 yang menunjukan bahwa makin tinggi kadar polifenol maka makin tinggi aktivitas antioksidan. 
Antioksidan memilki kandungan yang dimana salah satunya adalah polifenol. Penambahan puree buah pada yoghurt meningkatkan kadar polifenol karena buah memiliki senyawa karotenoid, flavonoid, fenolik, vitamin C, vitamin E, vitamin A, dan betalain (R., Nurliyana dkk, 2010). Dapat di simpulkan bahwa kadar polifenol berbanding lurus dengan aktivitas antioksidan jika dilihat hanya berdasarkan yoghurt dengan adanya penambahan puree buah.

Aktivitas antioksidan yoghurt rasa stroberi adalah yang paling tinggi. Hal ini sesuai dengan penelitian Ivavona dkk (2019) yang menyatakan bahwa selama penyimpanan pun yoghurt stroberi memiliki kandungan polifenol dan antioksidan yang sangat tinggi dengan kadar antioksidan sekitar 100-125 mol TE/100 ml. Senyawa biokatif yang sangat penting bagi kesehatan dalam stroberi adalah antioksidan alaminya seperti vitamin dan kandungan fenolik (Forbes-Hernández dkk, 2015). Pada buah tomat terdapat kandungan antioksidan yang disebutkan oleh Ibrahim dkk (2018) bahwa kandungan antioksidan tomat tertinggi berturut-turut berasal dari likopen, B-karoten, phytone dan phytopluene. Pada buah nanas terdapat vitamin A dan C yang berfungsi sebagai antioksidan dan antiradang. Nanas juga membantu melunakkan makanan dilambung, dan menghambat pertembuhan sel kanker. Serat pada nanas juga bisa mempermudah saat proses pengeluaran feses dari usus (Pridia, 2014). Sedangkan berdasarkan Sakrar (2018) Fenolat terlarut total, vitamin $\mathrm{C}$, likopen, dan total karotenoid ditemukan berkorelasi dengan total kapasitas antioksidan (TAOC) ekstrak hidrofilik dari buah jambu biji, yang TAOC diukur dengan menggunakan enam pengujian berbeda dimana salah satunya adalah DPPH.

\section{Karakteristik Organolpetik Yoghurt Ngeboon Panorama Indonesia}

Pengujian Organoleptik yang dilakukan adalah dengan menggunakan uji hedonik untuk mengetahui tingkat kesukaan panelis terhadap produk yang diujinya. Karakteristik organoleptik yoghurt dalam SNI 2981 (2009) dapat dilihat dari kriteria uji penampakan, bau, rasa, dan konsistensi.

Tabel 2. Karakteristik Organoleptik Yoghurt Ngeboon Panorama Indonesia

\begin{tabular}{cccccc}
\hline $\begin{array}{c}\text { Varian Rasa } \\
\text { Yoghurt }\end{array}$ & Warna & Kenampakan & Aroma & Tekstur & Rasa \\
\hline Stroberi & $3,833^{\mathrm{bc}}$ & $3,833^{\mathrm{a}}$ & $3,800^{\mathrm{a}}$ & $3,633^{\mathrm{a}}$ & $3,633^{\mathrm{a}}$ \\
\hline Nanas & $4,200^{\mathrm{c}}$ & $3,933^{\mathrm{a}}$ & $3,767^{\mathrm{a}}$ & $3,933^{\mathrm{b}}$ & $3,767^{\mathrm{a}}$ \\
\hline Jambu & $3,533^{\mathrm{ab}}$ & $3,700^{\mathrm{a}}$ & $3,467^{\mathrm{a}}$ & $3,733^{\mathrm{ab}}$ & $3,800^{\mathrm{a}}$ \\
\hline Tomat & $3,433^{\mathrm{a}}$ & $3,567^{\mathrm{a}}$ & $3,500^{\mathrm{a}}$ & $3,533^{\mathrm{a}}$ & $3,800^{\mathrm{a}}$ \\
\hline
\end{tabular}

Keterangan: Notasi yang sama menunjukan tidak berbeda nyata pada taraf signifikan $\alpha=5 \%$ menurut uji DMRT

Warna merupakan salah satu atribut mutu sensori yang seringkali menentukan penerimaan suatu produk pangan (Winarno, 2002). Suatu bahan pangan meskipun memiliki rasa yang dinilai enak, tetapi memiliki warna yang tidak menarik, maka akan mengurangi minat konsumsi konsumen. Bahkan warna dapat dijadikan parameter mutu yang pertama kali dipertimbangkan oleh konsumen sebelum menilai sifat sensori lainnya. Tingkat kesukaan warna yoghurt Ngeboon Panorama Indonesia memiliki nilai diantara 3,433-4,200 yang artinya suka hingga sangat suka. Yoghurt yang paling disukai warnanya adalah yoghurt rasa nanas karena mimiliki warna yang paling cerah dibandingkan dengan yoghurt vairan rasa lainnya yang berwarna lebih pekat.

Kenampakan dinilai dari keseluruhan tampilan yang dapat dilihat. Tingkat kesukaan kenampakan pada yoghurt Ngeboon Panorama Indonesia bernilai diantara 3,567 - 3,933 yang artinya kenampakan semua varian rasa yoghurt sangat disukai oleh panelis. Yoghurt yang paling disukai dari kenampakannya adalah yoghurt rasa nanas. Hal ini sesuai dengan Hamad (2019) yang mengatakan bahwa tingkat kesukaan warna dan kenampakan yoghurt nanas memiliki nilai kesukaan 14 dari 15 . Sebelum makanan dirasakan oleh indera pengecap atau lidah, indera pencium telah lebih dulu mendeteksi bau atau aroma yang ditimbulkan oleh makanan, sehingga aroma dapat lebih dulu mempengaruhi penilaian konsumen terhadap makanan tersebut. 
Tingkat kesukaan aroma yoghurt Ngeboon Panorama Indonesia memiliki nilai diantara $3,467-3,800$ yang artinya panelis sangat suka dengan aroma semua varian rasa yoghurt. Aroma yoghurt yang paling disukai oleh panelis adalah yoghurt rasa stroberi. Aroma asam didapatkan dari pemecahan glukosa dalam buah stroberi (Wijaya, 2018). Selain itu stroberi juga memiliki aroma khas yang berasal dari kandungan vitamin $C$ atau asam sitrat. Asam sitrat memiliki aroma sitrus yang khas dan segar (Diniyah dkk, 2011), sehingga dapat memberikan aroma yang segar pada yoghurt dengan varian rasa stroberi. Asetaldehid yang merupakan komponen flavor utama dalam yoghurt diproduksi dalam jumlah yang cukup oleh aktivitas simbiosis starter (Imelda dan Purwandani, 2017). Aroma yoghurt yang khas disebabkan adanya komponen asam laktat, dan senyawa-senyawa volatil lain yang diproduksi oleh starter. Pembentukan senyawa-senyawa tersebut akan lebih tinggi pada yoghurt yang menggunakan kultur campuran $L$. bulgaricus dan $S$. thermophiles (Tamime dan Robinson 2007).

Yoghurt Ngeboon Panorama Indonesia memiliki tingkat kesukaan tekstur bernilai 3,533 3,933 yang artinya panelis sangat suka dengan tekstur yang terdapat pada semua varian rasa yoghurt. Yoghurt yang paling disukai oleh panelis adalah yoghurt dengan varian rasa nanas. Hal ini sesuai dengan Hamad (2019) yang mengatakan bahwa nilai kesukaan tekstur yoghurt nanas adalah 30 dari 35. Yoghurt mempunyai tekstur semi padat atau smooth (Imelda dan Purwandani, 2017). Zat padat dalam susu berperan dalam pembentukan tekstur dan aroma yoghurt yang baik. Kandungan zat padat dalam susu yang optimal berkisar 15,5-16,0\% (Tamime dan Robinson, 2007). Kasein merupakan protein utama dalam susu yang terpengaruh oleh perubahan $\mathrm{pH}$ atau keasaman. Jika pH susu menjadi sekitar 4,6 atau lebih rendah, maka kasein tidak stabil dan terkoagulasi (menggumpal) dan membentuk gel yoghurt. Gel yoghurt ini berbentuk semi solid (setengah padat) dan menentukan tekstur yoghurt (Aurum, 2009).

Rasa merupakan salah satu faktor yang menentukan keputusan konsumen untuk menerima atau menolak suatu produk pangan. Rasa dimulai melalui tanggapan rangsangan indera pencicip hingga akhirnya terjadi keseluruhan interaksi antara aroma, rasa dan tekstur sebagai keseluruhan rasa makanan (Maharani, 2016). Tingkat kesukaan rasa pada yoghurt Ngeboon Panorama Indonesia memiliki nilai diantara 3,633 - 3,800. Hal ini menunjukan bahwa panelis sangat suka dengan semua varian rasa yoghurt Ngeboon Panorama Indonesia. Rasa yang paling disukai adalah yoghurt rasa tomat dan jambu. Sari buah biasanya dapat ditambahkan sebagai penguat cita rasa (Ayuningtias dkk, 2018). Menurut Imelda dan Purwandani (2017), yoghurt mempunyai flavor khas karena mengandung komponen flavor seperti diasetil, asetaldehid dan karbondioksida. Kandungan asam yoghurt cukup tinggi, sedikit atau tidak mengandung alkohol. Rasa asam pada yoghurt disebabkan oleh adanya asam laktat sebagai metabolit akibat aktivitas bakteri asam laktat dari starter. Rasa yoghurt Ngeboon Panorama Indonesia masih sesuai dengan SNI mengenai mutu yoghurt (SNI 2981:2009) yaitu rasa khas asam.

\section{KESIMPULAN}

1. Nilai warna pada yoghurt Ngeboon Panorama Indonesia berpengaruh nyata terhadap puree buah yang ditambahkan karena setiap buah memiliki kepakatan warna dan kandungan pigmen yang berbeda-beda.

2. Kadar polifenol dan aktivitas antioksidan tertinggi terdapat pada yoghurt dengan rasa stroberi dan terendah terdapat pada buah nanas.

3. Semua varian rasa yoghurt Ngeboon sangat disukai dari tingkat kenampakan, warna, aroma, tekstur dan rasa oleh semua panelis, terkecuali pada tingkat kesukaan warna pada yoghurt rasa tomat panelis hanya memberikan nilai suka. 


\section{DAFTAR PUSTAKA}

Abdul-Hammed, M., Bolarinwa, I. F., Adebayo, L. O., \& Akindele, S.L. (2016). Kinetics of the Degradation of Carotenoid Antioxidants in Tomato Paste. Advance Journal of Food Science and Technology Volume 1, Nomor 11.

Aurum, Fawzan Sigma. (2009). Kajian Karakteristik Fisiko Kimia Dan Sensori Yoghurt Dengan Penambahan Ekstrak Ubi Jalar (Ipomoea batatas L.). (Skripsi). Universitas Sebelas Maret, Surakarta.

Ayuningtyas, C. E., Waluyo, \& Susetyowati. (2018). Pengaruh Penambahan Sari Buah Jambu Biji (Psidium guajava L.) Terhadap Sifat Organoleptik Yoghurt Tempe. Jurnal Dunia Gizi, Volume 1, Nomor 2.

Cenariu, D., Pintea. A., Fodor, E. F., Bucak, M.N., Cenariu, M., Crisan, G. (2015). Cytotoxic Potential of Antioxidants from Tomatoes on Tumoral Cells. Bulletin UASVM Veterinary Medicine Volume 72, Nomor 2.

Chandra. (2013). Pembuatan Yoghurt Anggur Bali (Vitis Vinifera var. Alphonso Lavalle) : Proporsi Sari Buah dengan Susu Sapi Terhadap Aktivitas Antioksidan dan Sifat Fisikokimia Yoghurt Selama Penyimpanan. (Skripsi). Universitas Katolik Widya Mandala Surabaya, Surabaya.

Diniyah, N., Setiadji, Windrawati, W. S., Mayasari, L., (2011). Produksi Minuman Fungsional Rosella (Hibiscus sabdariffa) Dengan Cara Fermentasi Asam Laktat. Universitas Jember, Jember.

Effendi, Supli. (2012). Teknologi Pengolahan dan Pengawetan Pangan. Alfabeta, Bandung.

Forbes-Hernandez, T. Y., Gasparrini, M., Afrin, S., Bompadre, S., Mezzetti, B., Quiles, J. L., Giampieri, F., \& Battino, M. (2015). The Healthy Effects of Strawberry Polyphenols: Which Strategy behind Antioxidant Capacity?. Critical Reviews in Food Science and Nutrition.

Hamad, M. N. F., El-Sayed, S. M., \& Anees, R. R. (2019). Technology and Microbiological Studies on some Probiotic Dairy Beverages Fortified with Pineapple Pulp. J. Food and Dairy Sci., Mansoura Univ., Volume 10, Nomor 4.

Ibrahim, A., Daood, H., Bori, Z., \& Helyes, L. (2018). Using Infrared Spectroscopy for Tracking and Estimating Antioxidant in Tomato Fruit Fractions. European Journal of Engineering Research and Science, Volume 3, Nomor 5.

Ikhsanudin, Azis dan Ningsih, Lovita. (2017). Formulasi Krim Ekstrak Tomat (Solanumlycopersicum) dan Uji Aktivitas Antibakteria Terhadap Staphylocccus aeurus ATCC 25923. Bomeo Journal of Pharmascientech, Volume 1, Nomor 2.

Imelda, Fenny dan Purwandani, Ledy. (2017). Karakteristik Sensori Yoghurt Sinbiotik Ubi Jalar. Prosiding Seminar Nasional Penerapan Ilmu Pengetahuan dan Teknologi, Pontianak.

Indrayani. (2012). Model Pengeringan Lapisan Tipis Temu Putih (Curcuma Zedoaria Berg. Rosc). (Skripsi). Universitas Hasanuddin, Makassar.

Inggrid, H. Maria dan Isknadar, Albertus Reynaldi. (2016). Pengaruh pH dan Temperatur pada Ekstraksi Antioksidan dan Zat Warna Buah Stroberi. Prosiding Seminar Nasional Teknik Kimia "Kejuangan",Yogyakarta.

Ivavona, I., Dimotrova, M., \& Ivanov, G. (2019). Antioxidant Capacity of Yogurt Fortified with Polyphenol Extract from Strawberry Pomace. Prosiding Seminar Agrofood, Istanbul.

Maharani, D. (2016). Formulasi Bahan Pengenyal dalam Produksi Marshmallow Ekstrak Daun Black Mulberry (Morus Nigra). (Skripsi). Universitas Pasundan, Bandung.

Novita, M., Satriana, \& Hasmarit, E. (2015). Kandungan Likopen Dan Karotenoid Buah Tomat (Lycopersicum Pyriforme) Pada Berbagai Tingkat Kematangan: Pengaruh Pelapisan Dengan Kitosan dan Penyimpanan. Jurnal Teknologi Dan Industri Pertanian Indonesia, Volume 7, Nomor 1.

Nurliyana, R., Syed Zahir, I., Mustapha Suleiman, K., Aisyah M.R., \& Kamarul Rahim, K. (2010). Antioxidant study of pulps and peels of dragon fruits: a comparative study. International Food Research Journal 17. 
Pridia, Heni. (2014). Susu Kacang Susu Sehat Segala Usia +45 Resep Bikinan Sendiri. PT Gramedia Pustaka Utama, Jakarta.

Putriningtyas, Natalia D. dan Wahyuningsih, Siti. (2017). Potensi yoghurt kacang merah (Phaseolus vulgaris $L$ ) ditinjau dari sifat organoleptik, kandungan protein, lemak dan flavonoid. Jurnal Gizi Indonesia (The Indonesian Journal of Nutrition), Volume 6, Nomor 1.

Rahayu, Anita. (2019). Kadar Polifenol Pada Variasi Yoghurt Teh Menggunakan Kultur Caspian Sea. Universitas Pendidikan Indonesia, Bandung.

Samichah dan Syauqy, Ahmad. (2014). Aktivitas Antioksidan dan Penerimaan Organoleptik Yoghurt Sari Wortel (Daucus Carrota L). Journal of Nutrition College, Volume 3, Nomor 4.

Sanggih, P. R. A., Wahyudo, R., \& Ginarana, A. (2019). Efek Buah Nanas (Ananas comosus L. merr) Terhadap Penurunan Kadar Kolesterol Pada Penyakit Jantung Koroner (PJK). JK Unila, Volume 3, Nomor 1.

Sarkar, T. (2018). Guava Fruit: A Rich Source of Antioxidant. (Artikel). Acta Scientific Agriculture Volume 2.

Siregar, M. R., Harun, N., \& Yusmarini. (2016). Pemanfaatan Buah Belimbing Manis (Averrhoa carambola L.) Dan Buah Nanas (Ananas comosus L.) Dalam Pembuatan Permen Jelly. JOM Faperta, Volume 3, Nomor 1.

Standar Nasional Indonesia. (2009). SNI 2981:2009 Yoghurt. Badan Standardisasi Nasional, Jakarta.

Sumarlan, S. H., Susilo, B., Mustofa, A., dan Mu'nim, M. (2018). Ekstraksi Senyawa Antioksidan Dari Buah Strawberry (Fragaria $X$ Ananassa) dengan Menggunakan Metode Microwave Assisted Extraction (Kajian Waktu Ekstraksi dan Rasio Bahan dengan Pelarut). Jurnal Keteknikan Pertanian Tropis dan Biosistem, Volume 6, Nomor 1.

Supriyono, T., Murwani, R., dan Nurrahman. (2014). Kandungan beta karoten, polifenol total dan aktifitas "merantas" radikal bebas kefir susu kacang hijau (Vigna radiata) oleh pengaruh jumlah starter (Lactobacillus bulgaricus dan Candida kefir) dan konsentrasi glukosa. Jurnal Gizi Indonesia, Volume 2, Nomor 2.

Tamime AY, dan Robinson RK. (2007). Yoghurt - Science and Technology. Third Edition. CRC. Woodhead Publishing Limited. Cambridge-England.

Wijaya, Agata Haprani. (2018). Uji Organoleptik dan Total Asam Tertitrasi Yoghurt Susu Biji Nangka (Artocarpus heterophyllus) Dengan Penambahan Sari Buah Stroberi (Fragaria sp.) (Skripsi). Universitas Sanata Dharma, Yogyakarta.

Winarno FG. (2002). Kimia Pangan dan Gizi. PT. Gramedia Pustaka Utama. Jakarta.

Zainoldin, K.H. dan Baba, A.S. (2009). The Effect of Hylocereus polyrhizus and Hylocereus undatus on Physicochemical, Proteolysis, and Antioxidant Activity in Yoghurt. World Academy of Science, Engineering and Technology, Volume 36. 